\title{
Mentoring and Perpetuating the Entrepreneurial Spirit within Family Business by Telling Contingent Stories
}

\author{
Rob Smith
}

\begin{abstract}
7 amily businesses do not perpetuate themselves.
4 Entrepreneurs must nurture and propagate the val1 ues that led to the creation of the very thing most precious to them-their business. This of course depends on stability. Nor do these cherished values propagate themselves. To be made meaningful for others, and for future generations, family experiences, values, and achievements must be communicated to others via language, narrative and storytelling, or other forms embedded in the narrative such as symbols. Often a variety of different socially constructed stories may be necessary contingent upon situation, purpose, or need.
\end{abstract}

Keywords: entrepreneurial narrative, familial fable, mentorial tales, dynastic tales, contingent stories, biographical analysis

Used to be that my grandmother told me stories. They weren't her stories, exactly. They were stories that she had heard from her parents, and grandparents, and her uncles and aunts on the family farm in Lixnaw, in North Kerry.

These are the evocative words of the master storyteller Charles P. Pierce, a native of Massachusetts and author of American Stories (www.charlespierce.net). Pierce wrote of "communal memory" and of "telling the tribe its stories, so that the tribe might be better for it...." Although narrated in relation to itinerant stories, it is of significance to scholars of entrepreneurship and family business because it is in this very manner that much of the lore of business and entrepreneurship is passed down through generations, as a portable form of narrated philosophy. It is in such everyday (re)tellings that entrepreneurs and other family members pass on their stories to the rest of their tribe. Consideration of individual entrepreneurs and their families belonging to a collective tribe is profound because it invokes images of collective belonging. In this context, entrepreneur stories and their many variant forms can genuinely be regarded as tribal stories that transcend individual families. ${ }^{1}$

Nevertheless, all tribes are made up of families. Statistically, family businesses are the predominant business model worldwide, but there are different models and struc- tures of families, be they nuclear, patriarchal, matriarchal, or single-parent. This has important implications for developing theories of entrepreneurship and family business because it suggests that structure alone cannot be responsible for the domination and success of the family business model and that other contingent social forces must be at play. This invites consideration of the possibility of their being a contingency theory of entrepreneurial behavior influencing how we narrate entrepreneur stories. This is but one possible explanation. This work explores powerful narrative influences underpinning this dominance. Nevertheless, irrespective of what familial model is in play, the family operates as a hierarchical unit of organization in which a dominant individual(s) directs and influences the fortunes of other family members and to succeeding generations. In capitalist Westernized culture, the entrepreneur is often presented as a dominant individual to be eulogized. Few would deny entrepreneurs, as a genre, their success stories but such constructions are but one of many possible renditions available. Family units act as a unifying framework for individual and collective actions but are often taken for granted, or considered irrelevant to individual success. Families and family business are often conflated but are separable entities, thus this article weaves narratives of entrepreneurship and family business closer together.

This article examines such narratives as a private stock of stories told and retold as Familial Fable or, where there is no immediate family, Mentorial Tales. Bourdieu (1996) articulated the importance of habitus to families and narratives form part of habitus. This study focuses on family stories as the medium for transmitting familial and family business values across generations. Moreover, narrated values influence the operational effectiveness of family businesses.

Despite a call by Chau et al. (2003) to extend the theoretical horizons of family business research, the publication of qualitative research particularly in the area of narrative and narrative theory per se remains minimal. In considering why this is so it became apparent that there may be deeply philosophical and fundamental reasons behind this. It is obviously preposterous to suggest that entrepreneurial narrative is atheoretical because the subject matter of any phenomenon is capable of being theorized at an abstract level. However, being 
rooted as it is in the oral tradition and perpetuated as an everyday life philosophy, entrepreneurial narrative has little need of theory. This is because narrative encasement has become its naturalized habitat for presentation and consumption. In passing on knowledge, we tell appropriate stories, not swap theories. By appropriate, the author means contingent on circumstances, time, and setting. Interestingly, Gibb and Wilkens (1991) call for better stories, not better constructs. This article also makes a contribution to extant literature (and thus theory) by considering the place of stories and storytelling in a wider theoretical framework. In such a narrativebased framework, all forms of narrative transcend the theoretical because of their philosophical basis as portable life philosophies of action in an everyday context. This is so because to be an entrepreneur does not entail understanding the theoretical, it may merely entail enacting and engaging with a script. This article also addresses a question not covered by Kickul et al. (2005:5-8) who proffered no advice on how to measure stories. Indeed, how exactly does one measure stories? By their veracity, their prosaic quality, their narrative values or aesthetic pull? Obviously measuring stories is problematic. The author suggests we do so by virtue of their contingency in addressing the task/purpose in hand.

The five sections in this article collectively construct and develop a narrative theory for explaining how familial edifices act as incubators for the entrepreneurial spirit. In doing so, these sections address the what, how, why, where, and when questions that Whetten (1989) suggested are necessary for a paper to make a theoretical contribution. This protean narrative theory relating to the propagation of the entrepreneurial spirit in a mature business environment is relevant to any person who is or becomes an entrepreneur and to their families. The first section explores the role of the family unit and how entrepreneurial families help in the generation and perpetuation of value and values. Second- and third-generation entrepreneurial family dynasties are considered, as is the role of mentor figures in instilling values. Section 2 considers entrepreneurial proclivity within family business and conducts a literature review. Section 3 considers how mentoring can be conducted using narratives that instruct and inspire future generations to act entrepreneurially. It reports on empirical research identifying examples of such stories within a business community. Section 4 considers the roles of storytelling and mentoring in perpetuating virtuous circles of knowledge, value, and practice. Section 5 suggests avenues of future research.This article develops and extends theory in the field of entrepreneurship by considering the role of contingency theory in mediating how we tell entrepreneur stories.

\section{Exploring the Role of Family in Business}

This section highlights the importance of family and family values to entrepreneurship focusing on the family unit and family business in an everyday context where the entrepreneur spends a considerable amount of his or her working life. Being an entrepreneur is not a nine-to-five routine and the delineation between work and family time is often blurred. Also, it highlights an often untold story of the privileged (but nonetheless heroic) entrepreneur who gets a helping hand from family members. These are the entrepreneurs whom Stolze (1999) described as being among the most successful having the good fortune to be the sons and daughters of professional and entrepreneurial families. For Stolze they benefit from parental mentoring and inherited family contacts.

\section{The Family Unit}

Family units are important constructionist building blocks and breeding grounds for entrepreneurial proclivity. To Bourdieu (1996:19/21) definitions of family and words associated with it, such as house, home, household, while seeming to describe social reality actually construct it becoming collectively recognized at a hidden, more or less universally accepted level. For Wetherell (1997:309) families create a web of meaning socially reproduced across generations. This social reproduction of values as narrated via familial stories, permit the accumulation and transmission of capital (of all forms) across generations making families significant to entrepreneurship. Bourdieu (1996) argued that families generate economic, symbolic, and social capital. In family businesses the symbolic capital (name) and social capital (the collective familial business experience) are crucial. This cultural capital is socialized within families and influences the development of particular styles, modes of representation, confidence, and levels of accumulated self-assurance. One is socialized into becoming entrepreneurial and stories and storytelling play a significant part in this process which Bourdieu (1996:24) calls the transmission of "economic heritage." Also, Marwick (1996:61) argues that "social assumptions, moral attitudes, and everyday behavior are first learned at home" and for Kirby (2003:55) entrepreneurship "tends to pervade family life." Families are a repository of storied individual enterprise and values upon which enterprise thrives, creating a virtuous circle in which entrepreneurship and entrepreneurial families flourish.

\section{Entrepreneurial Families and the Perpetuation of Value}

Entrepreneurial and business families play a significant part in the genesis of the entrepreneurial spirit. By entrepreneurial family, the author means a family unit orientated toward achievement irrespective of whether the parents or siblings are or become entrepreneurs. It has more to do with productivity and being enterprising than with entrepreneurship per $s e$. However, the concept of the entrepreneurial family is not synonymous with the concept of an entrepreneur's family. 
Children raised within the immediate family of an entrepreneur may grow up in their shadow and rebel against the values espoused particularly if the entrepreneur (or spouse) is egotistical, tyrannical, stressed, and prone to bullying. This may even occur if the entrepreneur is successful and a fabulous parent. Nevertheless, there is social capital to be gained by being raised in such families where the everyday practice of entrepreneurship becomes naturalized and taken for granted.

Much of the material in relation to entrepreneurial families comes to us from the burgeoning small business literature under business families (Leach 1991). For example, Cooper and Dunkleburg (1987), Duchesneau and Gartner (1988), Scherer et al. (1998), Aldrich et al. (1997), Delmar and Gunnarsson (2000) and Aldrich and Cliff (2003) all examined the link between family background and entrepreneurial propensity and the effect of having a self-employed parent on starting a business. As a general rule, children raised in an entrepreneurial family are more prone to display entrepreneurial propensity than those who are not (Scherer et al.1989). This is in keeping with the notion of the "family influence repertoire" (Wetherell 1997:259), which relates to familial influence on career choice. It holds that if one's parents/relatives are engaged in a particular occupation, then descendents may follow suit. Anderson and Miller (2003:178) explored how entrepreneurial family background impacts the development of social and human capital resources, finding that entrepreneurs from humble socioeconomic family origins appeared to have limited social capital assets. One's chances of becoming socialized into entrepreneurship may be influenced by whether they are raised in a working class, or middle class family. Anderson and Miller (2003:32) found that persons from lower socioeconomic family backgrounds with a subsequent poor educational development were hindered in their development of human and social capitals. This is similar to the habitus argument expounded by Bourdieu (1996) as different social classes possess different social scripts. Thus, levels of entrepreneurial proclivity may be contingent on familial circumstances.

Research by Scherer et al. (1989) demonstrated that the presence of an entrepreneurial parent resulted in an increased expectancy of a child pursuing an entrepreneurial career because the parent provides a positive role model, which influences the child via social learning theory and by providing an insight into networking mechanisms turning perception into reality. Further research by Schindehutte et al. (2001) into female entrepreneurs and their children in entrepreneurial families looked at implications for family life, career aspirations, and entrepreneurial perceptions. Moreover, Aldrich et al. (1997) talk of a passing on of privilege from self-employed parents to children, while Delmar and Gunnarsson (2000) found that self-employed parents of nascent entrepreneurs contribute to the entrepreneurial proclivity of their children. In a similar vein, Aldrich and Cliff (2003) argue that families play a pervasive part in the formation of entrepreneurial propensity with entrepreneurship being embedded within business families at a tacit level where children learn from the experience of other family members. Such experiences are brought to us in stories. Katz (2004:233) stresses that he "grew up around parents who were business and civic entrepreneurs, which is to say that I grew up in a world of stories." Indeed, Katz likens life among entrepreneurs as being a storybook life in which compelling narratives resonate with one's emotions. For Katz, being weaned on such personal examples of entrepreneurial narrative both inspired and enlightened him and he talks of moving from telling a story to living it. This resonates with the tribalistic words of Charles Pierce.

One of the most basic values that contribute to the virtuous circle is morality as embedded in old-fashioned family values. Stanley (2000:172) emphasizes the influence of a stable family upbringing in the future success of self-made millionaires, citing happy marriage, love, personal qualities, frugality, running productive households, and thrift as being family values associated with the self-made rich. According to Stanley (2000:266) they place a value on attending their children's school events and extracurricular sporting activities; attend church together and generally make time for their family issues. The perpetuation of family values transcends the self and selfishness because in passing on important life lessons one influences the conduct of one's children and their offspring.

However, little has been written about the mentoring of values within entrepreneurial families; or of second- and third-generation entrepreneurs (Osborne 1991; Venkatapathy 1996); and entrepreneurial dynasties. This may result from eulogizing first-generation entrepreneurs; the association of entrepreneurship with nascence and individuality; embeddedness; and how we expect typical entrepreneur stories to be told. Moreover, scholars of entrepreneurship often focus on the role of the individual entrepreneur within a story ignoring the parts played by family members who mentor and support the entrepreneur.The absence of families in the cultural motif of entrepreneurship perhaps has its roots in narrating entrepreneur stories as heroic tales of overcoming adversity in childhood (e.g. the tragic entrepreneurs described by Kets de Vries [1977] who clashed with family). Admittedly, families exert a push-and-pull influence on the emotions of entrepreneurs but despite the veracity of poorboy-made-good stories not all entrepreneurs come from broken families - yet coming from a bourgeoisie family makes it difficult to narrate such tales of adversity.

The question of whether entrepreneurial propensity is transmittable across generations as a social capital is relevant 
and is influenced by quality of parenting. For example, Sarachek (in Casson 1990:442-446) categorized entrepreneurs by the nature of their childhood father-son relationship, finding that 50 percent of entrepreneurs had authoritative, supportive fathers who were invariably self-employed businessmen who influenced and shaped the actions of their entrepreneurial sons by supporting them emotionally; fostering an interest in the development of their character and business abilities; allowing them room for failure while striving for excellence by projecting masculine images of competence and strength. Sarachek also discussed mentorial brothers and mothers.

The notion of entrepreneurial families pervades the writings on Quaker entrepreneurship. Walvin (1997:39) argues that Quaker women were encouraged into education becoming schoolteachers, actively participating in creating a climate and culture in which entrepreneurship flourished. Quakers established their own system of schooling-teaching bookkeeping and making their children numerate and literate and thus highly employable within business circles. Quaker children were encouraged to read and tell stories. This virtuous system of mentorial communal learning was carried over into the workplace with the sons and daughters of the less successful friends apprenticed into the practice of business in loco parentis by the successful (Walvin 1997: 49-50).

\section{Entrepreneurial Dynasties as Entrepreneur Stories}

Acknowledging the existence of entrepreneurial dynasties runs contrary to accepted entrepreneurial mythology (of the self-made first generation parvenu), which ignores the importance of familial values in shaping entrepreneurs. Moreover, it accentuates the individual and individuality per se, distancing the individual from the family unit obscuring the influence of the entrepreneurial family in propagating and perpetuating entrepreneurial narrative. Hoy and Verser (1994:19) introduce the concept of "inter-preneurship" to describe the process of intergenerational entrepreneurship and the transformation of fortunes across generations. Hamilton (2001) refers to the complex, dynamic interplay between the different generations in a family, and between the individuals and the businesses they are running. Ram and Holiday (1993) discuss the influence of familial culture on the perpetuation of business. The influence of intergenerational entrepreneurship is visible in the biographies of individual entrepreneurs. Moreover, Smith and Wade (2005) argue that although traditional entrepreneur stories are seldom present in mature small family businesses, the entrepreneurial narrative is still present as an adventure story or business romance. Table 1 narrates two family business stories that relate to business dynasties of a very different nature-namely those of the Guinness and Hammer families.
We can learn much from such stories, albeit they were not written by the entrepreneurs themselves. The Guinness family story is a living monument to the collective energies of several generations of one family who have maintained their identity and lineage. The story of the Hammer family shows that a success story may have its roots in several generations of collective business knowledge. Both examples relate to trading upon entrepreneurial social capital. What is also apparent from reading these stories is that the type of entrepreneur stories each generation could tell was directly contingent upon their family upbringing.

A family name is a form of dynastic capital, making the study of family-histories, trees, genealogies, and dynastic tales-essential. Indeed, family stories form a significant part of our personal constructs. Who we are and where we came from is important to us. Family stories expand the life story of the individual embedded in a wider context of the family unit and its socioeconomic relations to society, communities, and posterity. They are part of our heritage and form a mental legacy recounted as anecdotes with the power to influence future events. Indeed, Sarachek (in Casson, 1990:439) argues that "family aggrandisement" motivated many a businessperson; and Steyaert and Bouwen (1997) consider "great family stories" a distinct category of entrepreneurial stories. Entrepreneurs are shaped by their heritage, upbringing, and attitudes and family names and ambitions are an integral part of this social process. ${ }^{2}$ Also, Levin (1993:82) argues that within family structures each person's experiences can be unique, albeit they can be mapped. Mapping entrepreneurial propensity across generations is problematic because much of the knowledge is not in the public domain but buried within life stories, biographies, and family journals. Family stories are also an active form of mentoring.

\section{The Role of Mentor Figures in Instilling Values}

Entrepreneurial knowledge within individual families is frequently passed down to future generations from grandparents, aunts, uncles, cousins, and extended family members via emotional kinship and mentoring. Such personages may not be the heroic entrepreneurial figurehead, but a background figure such as a mother or grandmother who perpetuates familial ideology via stories with a purpose. Hamilton (2001) argues that such support networks, such as family and domestic partners, impact significantly upon both the development of the entrepreneur and small firms. Furthermore, Sarachek (in Casson 1990:453) examined sponsor-protégé relationships echoing Warner and Abegglen (1955) and Collins and Moore (1964), stressing that successful businesspeople often encounter an influential mentor figure who proffer advice, personal influence, business contacts, loans, apprenticeships, and so forth. ${ }^{3}$ Having considered the pre- 
Table 1. The Importance of Families in Perpetuating Entrepreneurial Dynasties

The Guinness Family (Wilson 1998)

This story illustrates the process of intergenerational familial entrepreneurialism in action. The Guinness family are a legendary entrepreneurial dynasty, producing first-, second-, third-, and fourth-generation entrepreneurs. As a family with entrepreneurial flair they grasp their opportunities. The founder, Richard Guinness, fits the classic profile of the firstgeneration entrepreneur, being of modest beginningshomeless "Protestant Anglo-Irish" underclass descent. The industrious Richard was of privileged status in comparison to his Catholic counterparts. He gained employment with the Rev.Arthur Price and rose to become a land agent at the sharp end of English v. Catholic oppression. Price moved among the privileged circles in Irish society and Richard rose with his patron. Richard fathered six children and acquired a modest parcel of land. Legend has it that he brewed the dark distinctive beer. Despite his skills at social climbing Richard was no entrepreneur-it was his sons Arthur, Benjamin, and Samuel whose sound business instincts laid the foundations of the family fortunes. Richard's life work set his sons on an entrepreneurial trajectory in a new entrepreneurial age. On Price's death in 1752, Richard and Arthur both received stipends of $\$ 100$ (the proverbial millionaire's dime). Richard bought an inn, but the enterprising Arthur consolidated his existing businesses and acquired more land and property. The Guinness family joined the business community on the back of Arthur's mercantile athleticism. Unlike other entrepreneurial Irish they prospered at home.

\section{Armand Hammer (Hammer and Lyndon 1987)}

This hagiographic account of the now disgraced American entrepreneur Armand Hammer is deliberately written as an entrepreneur story replete with humble beginnings-living in a cold-water New York slum. Although Hammer sought to model himself upon America's self-made, he came from a long line of Russian businessmen. Evidence of his desire to narrate his life as an entrepreneur story comes from the prologue in which Hammer (one suspects insincerely) recites his personal creed as being "given the strength to help deserving people as much as I was able." Hammer apparently said this as a childhood prayer to God.Armand's peripatetic grandfather Jacob was the son of a wealthy shipbuilder who tragically lost his inheritance in a natural disaster. Jacob's first wife died and he married Victoria, the daughter of a prosperous merchant. The calamitous Jacob fancied himself as a shrewd businessman but his list of failures generated a negative form of familial fable. Jacob and Victoria's daughter married a wealthy entrepreneur Alexander Gomberg who turned the family fortunes around. Hammer attributes his business sense to mentoring by Gomberg. Jacob and Hammer's father Julius moved to America. Julius became a foundry worker before gaining employment in a drug store. He worked hard and bought out the elderly owner. Soon Julius had a chain of pharmaceutical shops but hankered to be an M.D. Julius's half brothers also owned drug stores. One family member was a successful salesmen and another was the owner of a traveling circus. It is thus not surprising that young Armand determined to become an entrepreneur. He narrates that he was inspired by his readings of the novels of Horatio Alger. A more plausible explanation is that his family history is steeped in business lore. Hammer also read the biographies of great American entrepreneurs such as Carnegie and became a child prodigy and millionaire by the age of 21 . Following in his fathers footsteps, he took over the running of the family drug stores. Hammer learned to tell a good entrepreneur story but, as with so much in his life, he was perhaps just being disingenuous as he was later unmasked as a Soviet spy. His story highlights powerful familial forces at play in creating the social capital from which the family dynasty benefited. ceding, it is incumbent to explore the role of family business in generating entrepreneurial proclivity as acknowledged by Baines and Wheelock (1997:1).

\section{Family Business and Entrepreneurial Proclivity}

This section explores family business as a channel for entrepreneurial activity. Family business is located at the margins of entrepreneurship, nonetheless, parallels exist between both literatures, in that individual family businesses, like the entrepreneur, are eulogized and share similar mythologies. One has to distinguish between myth and reality. In the family business literature, misconceptions and myth-conceptions abound. The most serious being that family businesses are nonentrepreneurial, yet, both revolve around the creation of value (Gartner 1990).
From a review of the literature on family business, namely Kets de Vries (1992), Storey (1994), Hamilton (2001), and Casson (1991, 1995, 2000), an interesting picture emerges from the overlapping literatures (as appreciated by Hoy and Verser 1994; Brockhaus 1994; and Baines and Wheelock 1997). Brockhaus (1994) points out that family business and entrepreneurship share a lack of common definition.

Gibb and Handler (1994:80) discuss various nexus points between entrepreneurship and family business, includingearly family experiences, family involvement and support in start-ups, employment of family members, and the involvement of family members in ownership and management and entrepreneurial succession. Goffee (1996) suggests that there are three main typologies of business owners-entrepreneurial, paternal, and familial custodial. Such differences may influence how individuals perform their roles within 
the family businesses. It is obvious that their stories will differ, albeit family business narratives continue the entrepreneurial adventure. Carsrud (1994:40) introduced the notion of the family business as an "emotional kinship group." Certainly, families can be a difficult dynamic to manage as arguments and tensions spill over into the business environment.

Perhaps the true value of family business to entrepreneurship is that it engenders the spirit of contradiction, opposition, and tension prevalent in entrepreneurship. Moreover, family business is a breeding ground for future entrepreneurs, providing them with the necessary experience and social capital to succeed, encouraging the spirit of insubordination necessary for the production of entrepreneurial flair. Fournier (1996) refers to a domestic imperative inherent in family business. Entrepreneurship and family business accommodate flexibility and diversity, but family business blurs the separation of market and home (Fletcher 2000) and often shapes individual entrepreneurs (Ram 1994). It is apparent that entrepreneurial values are socially (re)produced and embedded in family and familial structures and enterprise cultures. Family businesses permit the practice of inter- and intra-generational entrepreneurship, providing a natural setting for mentoring others by telling stories.

From an analysis of the above literature, it is apparent that the type of entrepreneur story that one can convincingly narrate is contingent on one's family background, one's life experience, and whether one has access to family members or mentors with entrepreneurship experience. Having discussed entrepreneurship, families, and family businesses from a theoretical perspective as encountered in the existing literature, it is helpful to discuss this theoretical insight in relation to some empirical research conducted by the author.

\section{Mentoring Others via Storytelling}

The author's interest in mentoring was first aroused by an appreciation that entrepreneur stories act as inspirational tales from which persons can learn how to become an entrepreneur (Smith 2002). The story acts as a surrogate mentor. In reading the biographies of entrepreneurs, the author developed an appreciation of the power of narrative as an aid to understanding the complexities of the entrepreneurial process. Common themes began to emerge between and across stories as hidden influences became visible in the form of mentoring within families, by significant others, and from external patrons and friends as well as in apocryphal stories. This section considers two types of narrative mentoring-familial fable and the mentorial tale (Smith 2002) as well as reporting on empirical research locating examples of both story types told by respondents.

\section{Familial Fable}

Exposure to narrative is a process of social construction and reconstruction that begins in childhood. Yet, entrepreneurship is essentially an adult paradigm. If children are not raised in a business environment, their knowledge of entrepreneurship may be limited. Buried deep in biographical rendition one finds nuggets of naturalized wisdom expressed as maxims, or proverbial sayings, pitched as sagacious homely advice often articulated by a family member reminiscent of familial fable. Such fables are eulogistic narratives relating to the exploits of a specific named individual, acting in the manner of a parable, embodying the themes of success and morality to inspire other family members to emulate them as role models personified. These hand-me-down-tales contain strong themes of proprietorial pride, morality, and success and exemplify MacIntyre's (1997:104) Home Spun Philosophies and Wetherell's (1997:304) "remembered sayings and philosophies of parents." These forms of narrated advice/internalized scripts have the propensity to influence and guide future behaviors. Table 2 details examples from the biographies of famous entrepreneurs providing theoretical underpinning.

Again we see that their ability to narrate examples of familial fable is contingent on them having access to such vignettes.

\section{Mentorial Tales}

The advice dispensed by external mentor figures is similar to that of familial fables and contains elements of parable and proverb. Entrepreneurial mentors also generate stories to be perpetuated by others as variations of the craft based master-apprentice narratives. Mentorial tales are eulogistic narratives relating to the exploits of a specific named individual acting in the manner of a parable embodying the themes of success and morality to inspire protégés to emulate them as role models personified.This definition mirrors that of familial fable.

\section{Empirical Research Reporting on Examples of These Pbenomena}

In addition to locating examples of familial fable and mentorial tales in novels and in biographies about entrepreneurs, the author also conducted empirical research-face-to-face interviews with eight small business owners/entrepreneurs located in northeast Scotland. It was apparent that their life stories also contained evidence of familial fable and significant levels of mentoring by others. Table 3 provides details of the respondents and their microbiographies.

The stories are about families in business not of family businesses per se. Nevertheless, they serve to illustrate the power of entrepreneurial narrative as portable philosophies. Of the eight respondents interviewed, four were classified as 


\section{Table 2. Examples of Mentoring from the Biographies of Entrepreneurs}

A familial fable (and perhaps an apocryphal story) relating to the legendary Irish entrepreneur Tony O'Reilly contained in the book The Player by Fallon (1994) hints at O'Reilly's alleged propensity for commercial deception, selling orange peels to classmates. It is a story told by his devoted mother and appreciated by his family.

Haines (1998:154), in discussing Robert Maxwell's favorite anecdote ("If a gentleman of the establishment offers you his word or his bond, always go for the bond"), is also illustrating the power of such advice. Maxwell appears to have been obsessed with dispensing wisdom in the form of maxims, homilies, and advice particularly where they related to his own experiences. Had his business empire survived these would no doubt have become familial fables.

In his autobiography, It's a Long Way from Penny Apples (Cullen 2002), Bill Cullen, a successful Irish entrepreneur, provides further evidence of the influence of the matriarch and of the power of familial fable when he recounts some of the homespun advice he received as a child from his mother. These vignettes/homilies are powerful motivators and include such examples as "You'll never meet a man better than yourself" and "Do your best at everything."

In the autobiography of Armand Hammer (Hammer and Lyndon 1987:58-59), there is an interesting example of reverse mentoring in which the seven-year-old Hammer as a protégé figure is introduced into the economics of the workplace by a family friend and farmer Mendal Kornblatt. The prodigious Hammer helped out at a Farmers' Market and arranged the produce for sale. According to Hammer he soon realized that his mentor was overpricing and told him so. When the market ended and his mentor had half his produce unsold, Hammer hectored him into hawking the fare around the grocery shops, late into the night, lest he suffer a loss. This (apocryphal story) weds Hammer to the American myth of childhood prodigies, hard-working days, and a flair for commercial acumen.

In the biography of Sir Thomas Lipton by Mackay (1998), it is interesting to read the paternalistic advice proffered by Lipton's mother. For example, "You're doing fine, Tom, but dinnae kill yersel working oor hard" (1998:73). This couthy advice is reminiscent of the familial fable. Mackay (1998:189) also discusses Lipton's chilling maxim "Never do business with an unsuccessful man." Furthermore, Mackay (1998:66-69) narrates the advice of Lipton's father that they were "only humble folks and should not build castles in the air for fear of riding for a fall." It is an admonishment against committing the entrepreneurial sin of hubris. entrepreneurs by attitude and example and four as small businesspeople. All were male and between the ages of 30 and 60 . The originators of the familial fables were all charismatic, enterprising individuals, who generated stories in abundance of achieving success in the face of adversity and of being moral. They were inspirational at two levels, having acted as role models and dispensers of practical business advice. This advice was packaged in the manner of moralistic "couthy, pithy wisdom" or sensible folklore. Examples of the advice include "They don't shoot you if you go bust," Dinnae be a thief, but take your profit," "Make a profit, everyone expects it."They inspired others by virtue of their basic honesty, character, and kindness and by propagating the work ethic by personal example. Such fables are replete with examples of stubborn pride, of hardship faced in the early years-searching jacket pockets for money to pay bills on time, of facing hunger rather than not paying a bill, and of overcoming financial losses. The power of such fable lies in its ability to inspire others to act and emulate the feats of their mentor. None of the respondents strike one as being Stolze's privileged entrepreneurs, and all give the appearance of being rooted in the working classes. However, the families in which familial fable circulate are privileged in that they possess a social capital that transcends the class restriction as envisaged by Anderson and Miller. Also, echoing Stanley's assertions about the importance of family values, seven out of the eight respondents had strong marriages with supportive families. None had reached the maturity that is necessary to legitimately tell dynastic tales or great family stories.

The content of actual familial fables is absorbed in childhood and may impact future entrepreneurial actions. General narratives, the parables, myths, and stories found in the public domain may also raise entrepreneurial awareness, but these personal tales acted as a directly inspirational and directive device. A striking point is that such personal tales inspire because they are so very personal and that they are also very limited in exposure. Respondents made comments such as, "I've never actually told anyone about this before...," "Only a few folk know this about my father...," "actually, he kept this very quiet, he was a modest man." Nonetheless it was made clear to the author that these tales had been influential in later shaping their conduct in business life. The significance of such stories is that outside business families few children appear to be exposed to them making it a privileged form of social capital. Two respondents were gifted their businesses by benevolent mentor figures who had no suitable offspring and were thus prevented from perpetuating familial fable. Instead they chose to propagate their life work by benevolent entrepreneurial transference. This arrangement is not unusual as Arlacchi (1983:80) refers to the pragmatic Southern Italian social practice of appointing Commessi or agents to run family businesses. These appren- 


\begin{tabular}{|c|c|c|}
\hline $\begin{array}{l}\text { Angus } \\
\text { E1 }\end{array}$ & F.F & $\begin{array}{l}\text { A full-time entrepreneur until recently, Angus was inspired by familial fables regarding an enterprising uncle } \\
\text { and by other familial business influences. Angus entered the pub trade at age } 20 \text { and built up a chain of city } \\
\text { center pubs, which he sold to a rival before entering the manufacturing trade. He later sold this and went on } \\
\text { to set up a thriving building business.Angus is indebted to an aunt who provided support in the form of famil- } \\
\text { ial fable and couthy advice such as "They don't shoot you if you go bust." Angus is blessed with an equally } \\
\text { entrepreneurial wife. Together they have propagated the familial fables to their sons who are both in busi- } \\
\text { ness in their own right. }\end{array}$ \\
\hline $\begin{array}{l}\text { Jay } \\
\text { E2 }\end{array}$ & F.F & $\begin{array}{l}\text { A part-time entrepreneur inspired by his upbringing in his father's business, Jay was thus socialized into the } \\
\text { entrepreneurial ethic and practices it effortlessly in many sidelines. He pursues a full-time career and bene- } \\
\text { fits from multiple income streams from selling and repairing cars, selling free range eggs, as well as clothing } \\
\text { on the Internet. Entrepreneurship appears to be in his blood and he still turns to his father for advice. }\end{array}$ \\
\hline $\begin{array}{l}\text { Bill } \\
\text { E3 }\end{array}$ & E.M & $\begin{array}{l}\text { A retired full-time entrepreneur with no prior business experience influenced by an external mentor, Bill was } \\
\text { the son of a farm laborer who overcame childhood illnesses that affected his education. Apprenticed as a } \\
\text { motor mechanic, he quickly acquired responsibility in the running of the garage business where he was } \\
\text { employed. He came into contact with "self-made-men"who inspired him. Serendipity, in the shape of a benev- } \\
\text { olent and mentorial bank manager, played a hand and he bought a garage premises. For more than } 40 \text { years } \\
\text { with the assistance of his wife, he built a thriving rural business employing } 12 \text { people. Bill became respect- } \\
\text { ed for his fair dealings and for the advice he dispensed. He remembers the advice he was given by senior } \\
\text { members of his peer group at the start of his business career,"Dinna be a thief ... but take your profit." Unusual } \\
\text { for a Scotsman, he was critical of "business conducted over a dram." His success resulted from his hard work } \\
\text { and unstinting attention to the operational problems of the business. He never sought to be a "big shot" or to } \\
\text { broadcast his success. He built an image of honesty, integrity, and probity. Many regard Bill as a paternalistic } \\
\text { businessperson and not an entrepreneur. Bill was an inveterate storyteller and loved nothing more than to } \\
\text { wile away the quiet hours by telling stories of business and of life. Having no sons he selflessly tutored a num- } \\
\text { ber of employees to enter business. He retired at } 70 \text {. }\end{array}$ \\
\hline $\begin{array}{l}\text { Dan } \\
\text { E4 }\end{array}$ & E.M & $\begin{array}{l}\text { A solo entrepreneur, Dan had no prior business experience. Apprenticed as a mechanic, he set out to seek } \\
\text { his fortune in the burgeoning oil business. He married and got a job on a pipeline. He was mentored by his } \\
\text { father-in-law who was a trader. Dan saved and opened a garage but this first venture failed. Penniless, Dan } \\
\text { worked on a pipeline in the Middle East to accrue capital. Back home from his travels, Dan dealt in second- } \\
\text { hand cars and lorries before setting up in the oil business. He did well until wiped out by the taxman. Dan } \\
\text { worked hard and recovered and now travels the globe buying and selling second-hand oil equipment and } \\
\text { scrap, acting as a middleman for other companies. He trades in older oil rigs but still lives by his wits buying } \\
\text { and selling cars on the side. He taught himself about finance and offshore banking, developing a vast network } \\
\text { of business contacts. He spends his time scouring the network for new deals. He is now into property devel- } \\
\text { opment as well as property deals in Africa and South America. He is aided by his equally entrepreneurial wife. }\end{array}$ \\
\hline $\begin{array}{l}\text { Danny } \\
\text { SB1 }\end{array}$ & B.E.M & $\begin{array}{l}\text { Until recently Danny was a full-time businessperson. He worked for a local joiner he considered his friend. } \\
\text { The employer who was childless died, leaving the modest business to Danny, his lifelong friend. Danny shoul- } \\
\text { dered the responsibility he had never sought nor believed he would ever have to carry. He kept the business } \\
\text { ticking over, but was not a businessperson by nature. He made a success of it but later merged his business } \\
\text { with that of his sons. He is still working at } 75 \text {. }\end{array}$ \\
\hline $\begin{array}{l}\text { Vick } \\
\text { SB2 }\end{array}$ & F.F & $\begin{array}{l}\text { Vick, the family-orientated son of SB1, was inspired by his father and is now on his way to becoming an } \\
\text { entrepreneur. At school, Vick made modest progress and entered the same builder's firm that his father } \\
\text { worked at. He steadily learned his trade and became a "jack of all trades." He was a quiet, industrious child } \\
\text { by all accounts. Vick worked for his father until in his mid-20s but did not want to live all his life under his } \\
\text { father's shadow. Inspired by his father's progress, he decided to take the plunge. Through a friend in the } \\
\text { trade, he was offered a building contract but he had to buy the materials himself. Newly married with a small } \\
\text { child, he nevertheless used all his savings and ran up a considerable overdraft before the deal finally paid } \\
\text { off for him. His memories are of sitting at the kitchen table in the evenings wondering how he would pay } \\
\text { his debts and feed his family. Slowly,Vick began to prosper. He bought an old van and was soon employing } \\
\text { two local men. Over a period of two years his business expanded and he employed several other laborers. } \\
\text { He prospered because of his hard work, long hours, and his meticulous attention to costs and details. His } \\
\text { reputation grew and he took on council contracts. He diversified into other areas such as landscape garden- } \\
\text { ing, property speculation, and house building. He bought his father's firm and now as he nears his mid-40s } \\
\text { employs } 29 \text { men. }\end{array}$ \\
\hline
\end{tabular}


Table 3 continued

\begin{tabular}{|l|l|l|}
\hline $\begin{array}{l}\text { Alan } \\
\text { SB3 }\end{array}$ & B.E.M & $\begin{array}{l}\text { Alan is a full-time businessperson who, like SB1, was practically gifted a business by his former employer who, } \\
\text { having no sons, tutored him over several years and sold him the business cheaply. This benevolent mentor } \\
\text { tutored him as a surrogate son.Alan is a bachelor and has two other careers that he pursues in his spare time. }\end{array}$ \\
\hline $\begin{array}{l}\text { Alfie } \\
\text { SB4 }\end{array}$ & E.M & $\begin{array}{l}\text { A retired full-time businessperson who had no prior familial business experience, Alfie was raised in a rural } \\
\text { village environment in the 1930s. He began work as a farm laborer and then as a joiner. In his 20s he mar- } \\
\text { ried. He was friendly with other young men who were the sons of shopkeepers, bakers, publicans, and small } \\
\text { business owners. He socialized with them and over a pint in the pub would listen to their stories of business } \\
\text { success and failure. He became a well-respected joiner noted for his craftsmanship and skill. When the local } \\
\text { joiner retired, Alfie bought the business. It was a steep learning curve. He remembers searching his jacket } \\
\text { pockets for pennies to pay a bill. He often went without food himself to pay his bills on time. Alfie worked } \\
\text { hard and slowly saved money. He employed two local men but chose to remain small. He saw from watch- } \\
\text { ing his peers that expanding rapidly and being the big man did not always pay. He took pride in his expand- } \\
\text { ing bank balance. When the local undertaker died, Alfie diversified and between the two businesses pros- } \\
\text { pered. He is a deeply moral man and a devoted husband. It is a classic case of a family in business as opposed } \\
\text { to a family business. }\end{array}$ \\
\hline
\end{tabular}

tices were trusted boys from poor local families. Often they married the boss's daughter and were gifted the business upon marriage, infusing native entrepreneurial talent from below.

\section{Contingent Stories, Mentoring, and the Virtuous Circle}

The entrepreneurial spirit can reinvigorate family businesses via physical and narrative processes forming a virtuous circle of knowledge, values, and practices that surrounds the family unit. Whetten (1989) argues that the construction of diagrams assists in the theory-building process. Figure 1 illustrates how contingent narratives mentor and initiate enterprise within the family unit and business environment. By a process of assimilation, this spirit is infused into the family business environment.

The entrepreneurial mentee stands between the family unit and business, drawing inspiration from three related narrative spheres: family, external mentor, and family business. The family unit generates familial fable, entrepreneur stories, great family stories, and dynastic tales. The mentee can draw inspiration from external sources such as a mentor figure, mentorial tales, or self-educate by reading inspirational texts about entrepreneurs. The family business generates its own story that in time may influence familial fable. A series of linked stories emerge as each family member contributes to the family business in different ways. Thus, the male father figure may adopt the role of entrepreneur. The mother may direct the play (Hamilton and Smith 2006) behind the scenes, or act as an equal partner.The siblings may enact managerial roles as entrepreneurs-in-waiting. It is a complex interaction of narrated behaviors and the type of story a family member chooses to narrate is contingent on a variety of circumstances both personal and social, depending upon the setting. To one person the male head of the family business may narrate a traditional entrepreneur story and to another he may emphasis the family business story. His wife may narrate the exploits of her husband with pride as an entrepreneur story. In different circumstances she may narrate the same events as an adventure or romance story where both she and her husband are entrepreneurs. Alternatively they can also legitimately narrate their story as part of a wider dynastic picture. Figure 2 continues this theme, showing where the above elements fit into the anthology of stories available to the entrepreneur and their families.

Thus, the mentee-entrepreneur is surrounded by a selfreinforcing virtuous circle of stories from which it is possible to construct their moral universe, shape character, guide attributes and beliefs forged by events and doxic scripts in a potentially bewildering variety of ways. Which story they can and do tell will be contingent on the purpose behind the telling. All the possible stories may be appropriate, but it is the contingent circumstances surrounding the narration that will dictate which story is the most situationally specific. The construction of the diagrams led to a realization on the part of the author of the power of contingency theory in helping make sense of families in business.

\section{Making Sense of Families in Business}

This study focused on family stories as transmitters of familial and family business values across generations as narratable entrepreneurial capital.Also, in considering the family unit as an entity separable from the family business and in examining the perpetuation of family values into the business sphere, this work takes a step forward by linking both to narrative and narration-for it is in stories that circulate within business communities that one makes sense of families in business.

We have come to expect our entrepreneur stories to be about energetically overcoming hardships and succeeding. Stories of matured entrepreneurship such as those discussed in this article as familial fable are about stamina, renewal of 
Family Background-entrepreneurial

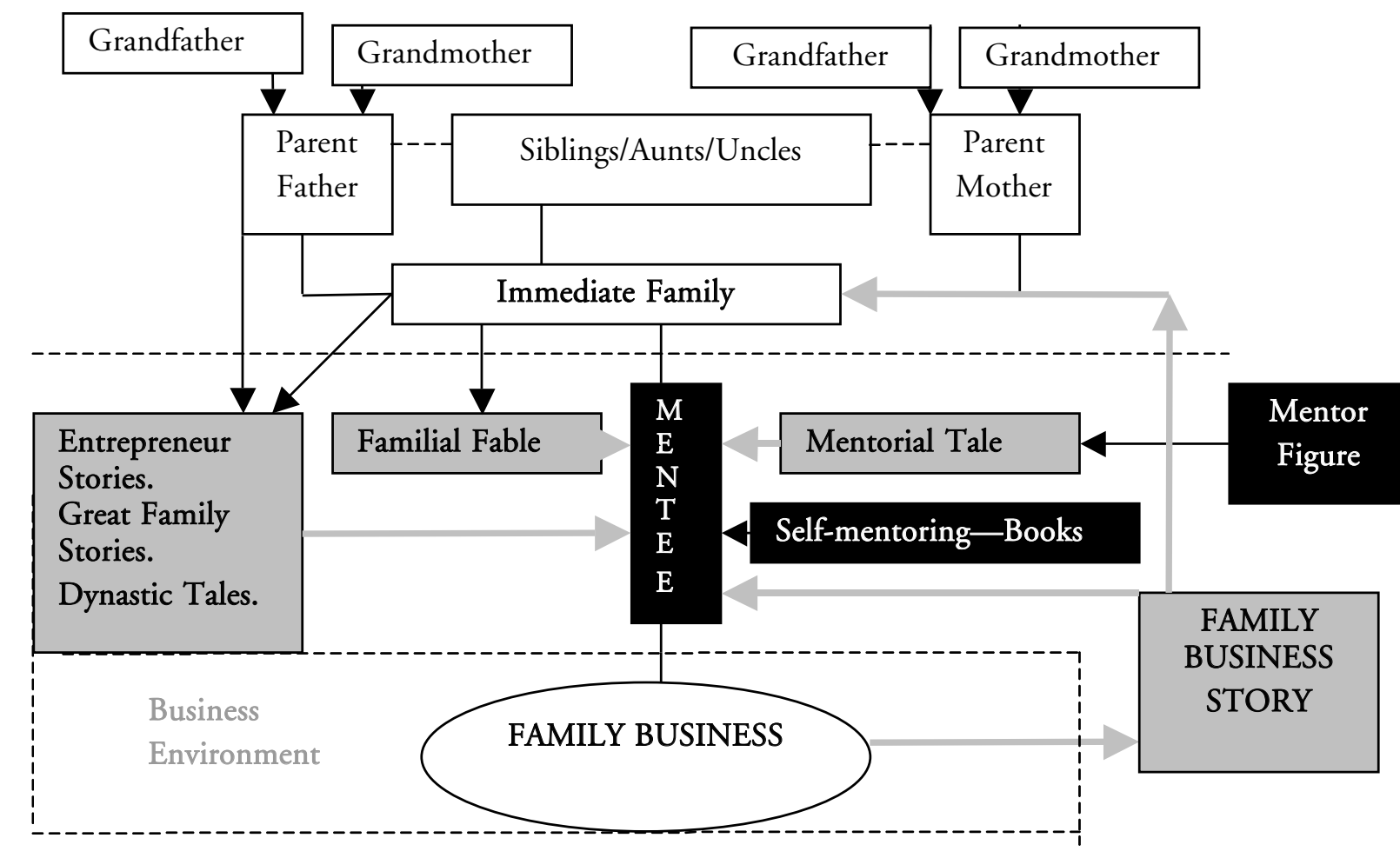

Figure 1. The Contingent Nature of Narratives of Family Enterprise

values, and dealing with change. The stories are part of the same genre because the entrepreneurs discussed herein are no different from the other first-generation entrepreneurs, only the way in which they can tell their stories differ. Nevertheless, holistic approaches help us make sense of the complex issues that obscure how knowledge of entrepreneurship, small business, and family business is passed on to future generations. Acknowledging the existence of this rich stream of narrated knowledge circulating within business communities is a major contribution. When familial fable and mentorial tales are placed alongside existing narrative categories such as great family stories, dynastic tales, family business stories, and entrepreneurial family stories, one senses the importance of narrative as a sense-making device. Over time, social commentators and academics lost sight of the importance of families and family values in propagating and perpetuating the entrepreneurial spirit.They forgot about the most directive social organizations in the world-the family. To make sense of entrepreneurship enacted in small and family businesses, researchers would benefit from listening to stories from the business milieu and attempt to map and understand what they mean collectively because in theory and in practice, entrepreneurship manifests itself in many forms. Thus, one story does not fit all.

The author considers entrepreneurship to be a modus operandi or method of operating with actantial, as well as communicational elements. The propagation of entrepreneurial narrative makes it a practice. Despite the existence of a significant body of literature on narrative theory, narrative inclines more toward the practical. Furthermore, the author also considers entrepreneurial behavior (as recounted in narrative) to be more of a peripatetic philosophy than a theory being a portable wisdom embedded in stories that can be passed onto others as we walk and talk through life. In relation to the familial fable and mentorial tales discussed, it is dispensed by those who care about us, so it has a powerful, authoritative effect. Perhaps entrepreneurial narrative is more akin to being a peripatetic form of philosophy than a theoretical construct. As such it is resistant to theorizing, which is just too dispassionate and analytic an activity for everyday situations. Attempts to conceptualize it as one theory fail to convince because they lose sight of the complex humanities and essences expressed in entrepreneurship. Narratives and stories convince because they can convey 


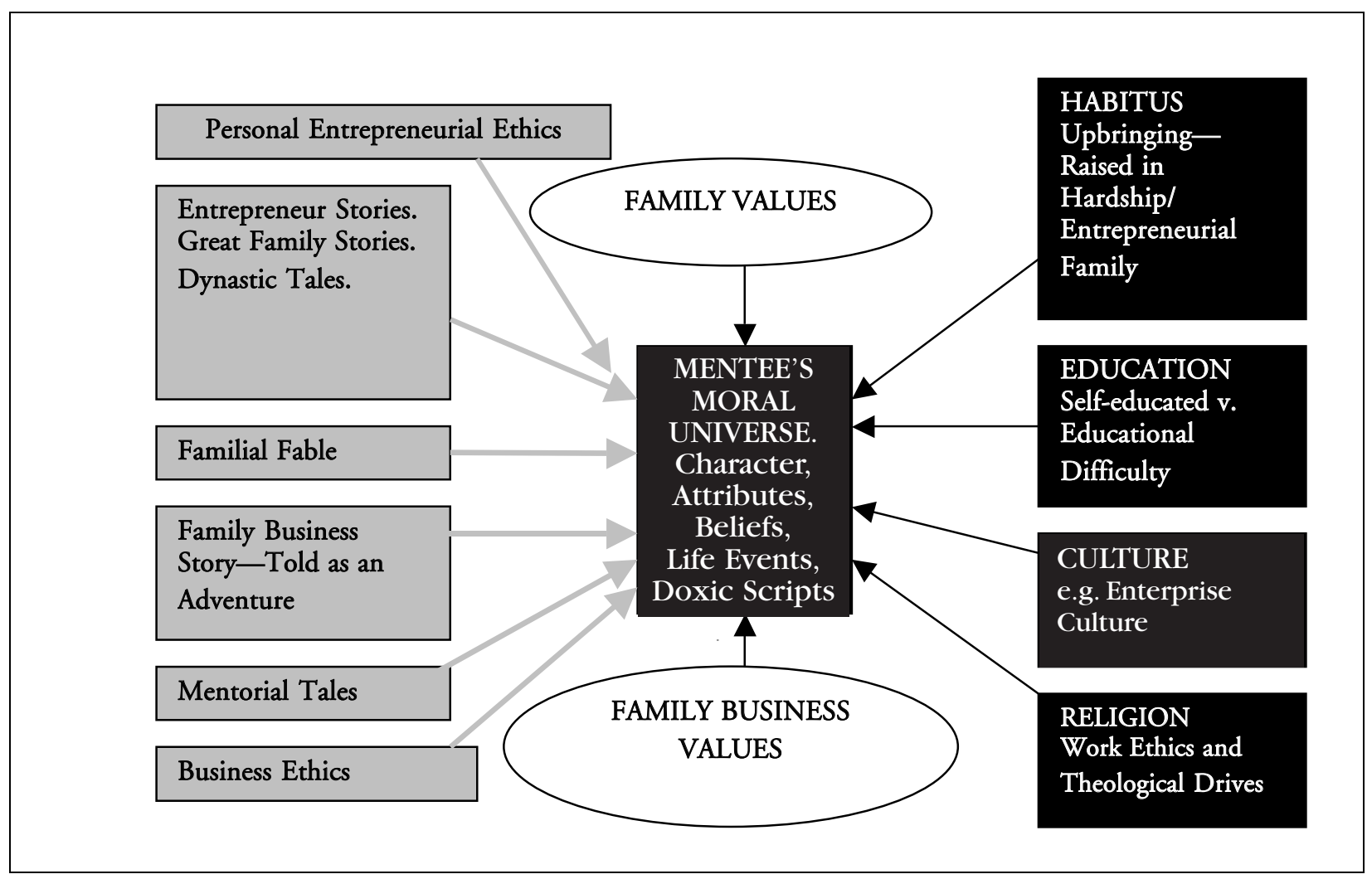

Figure 2. A Self-Perpetuating Virtuous Circle of Morality within Family Business

emotions and essences with greater humanity than can be achieved in theory. The author appreciates that even in identifying a contingency theory for telling appropriate entrepreneur stories that it will make little difference to the actual stories told.

This article has the potential to make a contribution by informing future research by providing a unifying theoretical platform to incorporate the many narratives, stories and other theoretical stances associated with entrepreneurship such as the behavioral approach, the trait approach, and so forth.These can be accommodated as enacted stories and storylines. It does not matter that one story does not fit all because of the adaptability of contingent stories.

Moreover, simply proposing that entrepreneurship is a philosophy of the everyday variety does not end the debate because it is not one philosophy either. Being a philosophy one can buy into the elements that resonate with one's ideals and belief system and ignore those that do not. The belief system as discussed in the article is that of moral entrepreneurship but the author accepts that immoral, amoral, and criminal belief systems can be brought into play in practicing entrepreneurship. Framing entrepreneurship as a portable life philosophy does not necessitate the application of a theoretical framework of philosophy incorporating other philo- sophical theories and theorists. This is because everyday philosophy works with the pool of knowledge at hand bypassing the theoretical. It enables us to move on to the practical and the practice of entrepreneurship, acting as a conceptual bridge between theory and practice. The philosophical element enables practical application.

There is a double problematic in that stories have to be told, memorized, practiced, and repeated to be effective.They have to be collected and faithfully reproduced or they lose their purpose. Stories contain their own morale and are selfcontained moral universes/cosmologies. Stories illustrate and transfer values in everyday contexts. To be effective they have to contain embedded cultural aesthetics and one has to stick very much to the script. Also, character aspects are paramount in telling convincing stories. Future generations of entrepreneurs will continue to hear such tribal stories from their grandparents, their uncles, and aunts and in this way, to paraphrase Pierce, "be better off for it."

To conclude, entrepreneurial narrative in its many forms may lean toward being a practical theory (as proposed by Rae 2004). However, the problem with advocating practical theories is that they just don't look and sound like theories at all, which makes the argument for telling contingent stories even more convincing. 


\section{Notes}

1.The author accepts that by making the deliberate decision not to review/discuss narrative theory he is holding himself a hostage to fortune. However, the author has tackled this elsewhere (see Smith and Anderson 2004).

2. However, for Casson (2000) entrepreneurship is only one form of social advancement with intermarriage into/and between entrepreneurial families being another option. Beaumont (2002) refers to the judicious marriage as an entrepreneurial strategy and Walvin (1997) documents intermarriage as a Quaker dynastic strategy.

3. In the novel Captains and Kings, Taylor Caldwell's heroic entrepreneur Joseph Armagh is mentored by a senator and a crooked businessman.

\section{References}

Aldrich, H., L. Renzulli, and N. Laughton. 1997. Passing On Privilege: Resources Provided by Self-Employed Parents to their SelfEmployed Children. Paper presented at the American Sociological Association.

Aldrich, H. E., and J. E. Cliff. 2003. The pervasive effects of family on entrepreneurship: towards a family embeddedness perspective. Journal of Business Venturing 185 (9).

Anderson,A. R., and C. J. Miller. 2003. 'Class matters': Human and social capital in the entrepreneurial process. Journal of SocioEconomics 32, 17-36.

Arlacchi, P. 1993. Men of dishonor: Inside the Sicilian Mafia (M. Romano,Trans.). New York: Morrow.

Baines, S. and J. Wheelock. 1997. A business in the family: An investigation of the contribution of family to small business survival, maintenance and growth. Institute for Small Business Affairs, Research Series-Monograph No. 3.

Beaumont, R. 2002. The railway king:A biography of George Hudson railway pioneer and fraudster. London: Headline Book Publishing.

Bourdieu, P. 1996. On the family as a realized category. Theory, Culture and Society 13 (3), 19-26.

Brockhaus, Sr., R. H. 1994. Entrepreneurship and Family Business Research: Comparisons, Critique, and Lessons. Entrepreneurship, Theory \& Practice 19 (1), 25-38.

Caldwell, Taylor. Captains and kings. 1977. London: Fontana.

Carsrud, A. L. 1994. Meanderings of a Resurrected Psychologist or, Lessons Learned in Creating a Family Business Program. Entrepreneurship, Theory \& Practice 19 (1), 39-48.

Casson, M. C. 1991. Economics of business culture: Game theory; Transaction costs and economic performance. Oxford: Clarendon Press.

Casson, M. C. 1995. Entrepreneurship and business culture. Aldershot: Edward Elgar.

Casson, M. C. 2000. Enterprise and leadership: Studies on firms, markets and networks. Aldershot: Edgar Elgar.

Chau, J. H., J. J. Chrisman, and L. P. Steier. 2003. Extending the theoretical horizons of family business research. Entrepreneurship Theory and Research 29 (4).

Collins, O. F., and D. G. Moore. 1964. The enterprising man. East Lansing Bureau of Business and Economics Research. Graduate School of Business Administration. Michigan State University.

Cooper, A.C., and W. C. Dunkleburg. 1987. Entrepreneurial research: old questions, new answers and methodological issues. American Journal of Small Business 11 (93), 219-234.

Cullen, B. 2002. It's a long way from penny apples. London: Hodder.

Delmar, F., and J. Gunnersson. 2002. How Do Self-Employed Parents of Nascent Entrepreneurs Contribute? Paper presented at the Babson Entrepreneurship research Conference, Wellesley, M.A.

Duchesneau, D. A., and W. B. Gartner. 1988. As of dominant religions to enterprise in Japan and England, profile of new venture success and failure in an emerging industry. In Kirchhoff, B.A. et al., eds., Frontiers of Entrepreneurship Research. Babson College, Wellesley, M.A, 372-386.

Fallon, I. 1994. The player: The life of Tony O'Reilly. Hodder and Staughton.

Fletcher, D. 2000. Family and Enterprise. In S. Carter and D. Jones-Evans, eds. Enterprise and Small Business: Principle, Practice and Policy. Pearson Education Limited. 
Fournier V. 1996. The concept of the profession and its inscription in the discourse of enterprise. Paper presented at the ISA Working Group 02-Occupations and Professions: Changing Patterns, Definitions and Classifications, Nottingham.

Gartner,W. B. 1990. What are we talking about when we talk about entrepreneurship? Journal of Business Venturing 5, 15-28.

Gibb D. W., and W. Handler. 1994. Entrepreneurship and Family Business: Exploring the Connections. Entrepreneurship Theory and Practice 19 (1), 71-83.

Gibb, D. W., and A. L. Wilkens. 1991. Better stories, not better constructs, to generate better theory: A rejoinder to Eisenhardt. Academy of Management Review 16 (3), 63-69.

Goffee, R. 1996. Understanding family businesses: issues for further research. International Journal of Entrepreneurship, Behaviour and Research, 36-48.

Haines, J. 1988. Maxwell. London: Futura.

Hamilton, E. 2001. Myth and Misconceptions. Lancaster University Business School-Internal Report.

Hamilton, E., and R. Smith. 2006. Directing the Play. Unpublished Working paper.

Hammer, A., and N. Lyndon. 1985. Hammer: Witness to bistory. London: Coronet Books.

Hoy, F., and T. G. Verser. 1994. Emerging Business, Emerging Field: Entrepreneurship and the Family Firm. Entrepreneurship, Theory \& Practice 19 (1) Fall, 9-23.

Katz, J. 2004. Reading the storybook of life: telling the right story versus telling the story rightly. In Hjorth, D. and C. Steyaert, Narrative and discursive approaches in entrepreneurship: A second movements in entrepreneurship book. Cheltenham: Edward Elgar.

Kets de Vries, M. F. R. 1977.The entrepreneurial personality: a person at the crossroads.Journal of Management Studies 14 (1), $34-57$.

Kets de Vries, M. F. R. 1992. The family firm: An owners manual. Fountainebleau: INSEAD Discussion Paper 92/03/OB.

Kickul, J., N. Krueger, and S. Maxfield. 2005. Measurement issues in entrepreneurship studies. The New England Journal of Entrepreneurship 8 (2), 5-8.

Kirby, D.A. 2003. Entrepreneurship. London, McGraw-Hill.

Leach, P. 1991. The family business. London, Kogan Page.

Levin, I. 1993. Family as mapped realities. Journal of Family Issues 14 (1), 82-91.

MacIntyre, B. 1997. The Napoleon of crime:The life and times of Adam Worth-the real Moriarity. London: Harper Collins.

Mackay, J. 1998. The man who invented himself: A life of Sir Thomas Lipton. London: Mainstream Publishing.

Marwick, A. 1996. British society since 1945. 3rd ed. Harmondsworth, UK: Penguin.

Osborne, R. L. 1991. Second-Generation Entrepreneurs: Passing the Baton in the Privately Held Company.Management Decision 29 (1), 42-47.

Rae, D. 2004. Practical theories from entrepreneurs' stories: discursive approaches to entrepreneurial learning.Journal of Small Business and Enterprise Development 11 (2), 195-202.

Ram, M. 1993. Managing to survive: Working life in small firms. Oxford: Blackwell.

Ram, M., and R. Holiday. 1993. Keeping it in the family: Small firms and familial culture. In F. Chattenden, M. Robertson, and D. Watkins. Small Firms, Recession and Recovery. London: Paul Chapman.

Scherer, R. F., J. S.Adams, S. S. Carley, and F.A.Wiebe. 1989. Role Model Performance Effects on Development of Entrepreneurship. Entrepreneurship Theory \& Practice 13 (3), 53-71.

Schindehutte, M., M. Morris, and C. Brennan. 2001. Female entrepreneurs and their children: Implications for family life, career aspirations and entrepreneurial perceptions. Paper presented at the Babson 2001 Conference, Jonkoping Sweden.

Smith, R. 2002. Inspirational tales: Propagating the entrepreneurial narrative amongst children. Paper presented at the BabsonKauffman Entrepreneurship Research Conference, Boulder.

Smith, R., and A. R.Anderson. 2004. The devil is in the e-tale: Form and function in the entrepreneurial narrative. In Daniel Hjorth and Chris Steyaert, eds., Narrative and discursive approaches in entrepreneurship. Cheltenham, UK: Edward Elgar. 
Smith, R., and G. Wade. 2005. Selling Selves and business: The communication of value in lived business narratives. Paper presented at the 4th Annual Rural Entrepreneurship Conference,Aviemore, November.

Stanley,T. J. 2000. The millionaire mind. Kansas City:Andrews McMeel Publishing.

Steyaert, C., and R. Bouwen. 1997.Telling stories of entrepreneurship-towards a contextual epistemology for entrepreneurial studies. In R. Donckels, and A. Mietten, eds., Entrepreneurship and SME research: On its way to the next millennium. Aldershot.

Stolze, W. J. 1999. What makes an entrepreneur? www.morebusiness.com. Accessed on June 6, 2006.

Storey, D. J. 1994. Understanding the small business sector. London:Thomson.

Venkatapathy, R. 1996. First and Second Generation Entrepreneurial Types. Journal of Social Behaviour and Personality 1, 471-472.

Walvin, J. 1997. The Quakers, money and morals. London: John Murray, Abermarle Street.

Warner, J., and J.Abegglen. 1955. Occupational mobility in American business and industry. Minneapolis.

Wetherell, M. 1997. Identities, groups and social issues. London, The Open University, Sage Publications.

Whetten, D. A. 1989. What constitutes a theoretical contribution? Academy of Management Review 14 (4), 490-495.

Wilson, D. 1998. Dark and light:The story of the Guinness family. London:Weidenfeld and Nicolson.

\section{About the Author}
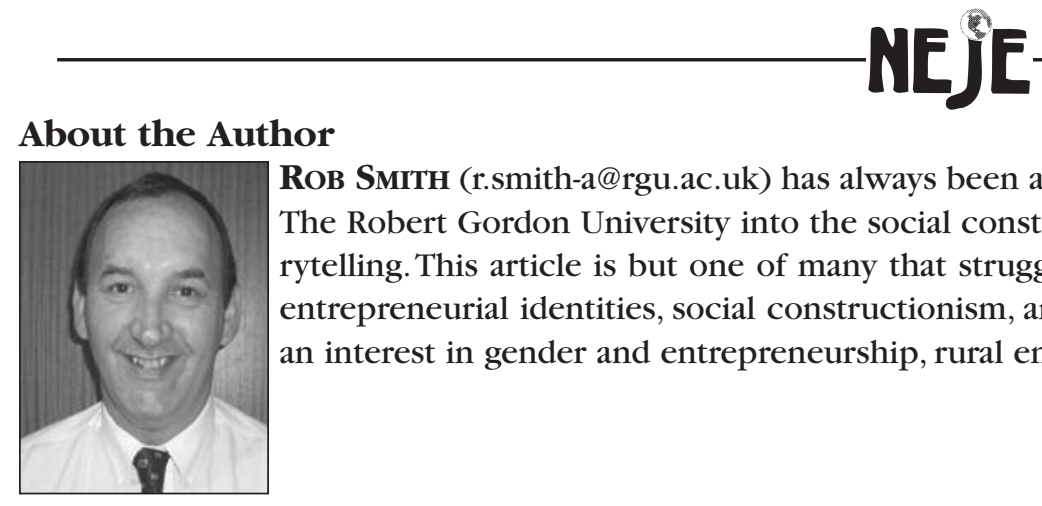

Roв SMITH (r.smith-a@rgu.ac.uk) has always been an avid reader of books and stories. His PhD by research at The Robert Gordon University into the social construction of entrepreneurship rekindled his passion for storytelling. This article is but one of many that struggle to articulate the nuances of entrepreneurial narrative, entrepreneurial identities, social constructionism, and semiotics which pervade the genre. Dr. Smith also has an interest in gender and entrepreneurship, rural entrepreneurship, and criminal entrepreneurship. 